\title{
SELECTION OF MICROORGANISMS FOR BIOSURFACTANT PRODUCTION USING AGROINDUSTRIAL WASTES
}

\author{
Marcia Nitschke*; Cristina Ferraz; Gláucia M. Pastore \\ Laboratório de Bioquímica, Departamento de Ciência de Alimentos, Faculdade de Engenharia de Alimentos, Universidade \\ Estadual de Campinas, Campinas, SP, Brasil.
}

Submitted: February 18, 2002; Returned to authors: February 10, 2004; Approved: April 23, 2004.

\begin{abstract}
Biosurfactant production by some bacterial isolates using molasses, milk whey and cassava flour wastewater (manipueira) as substrates was evaluated and compared with the production in conventional medium. Isolates growing in manipueira medium decreased the surface tension around $42 \%$, the highest reduction among all the substrates tested. From the eleven isolates tested, eight were able to decrease the surface tension to levels below $30 \mathrm{mN} / \mathrm{m}$ using manipueira as substrate. The isolates LB5a, LB2a, LB262, LBB and LB1a that gave surface tension about $26 \mathrm{mN} / \mathrm{m}$ were identified as Bacillus sp. Natural manipueira (high solids content) and decanted manipueira (no solids) were investigated as culture media for biosurfactant production by selected microorganisms. Natural manipueira medium showed minimum surface tension of $28 \mathrm{mN} / \mathrm{m}$ (LB5a isolate) whereas for decanted manipueira the lowest value was $26 \mathrm{mN} / \mathrm{m}$ (isolate LB2a). Average diameter of growth on manipueira agar was 7.2 $\mathrm{cm}$ for isolate LB5a suggesting a high growth capacity on this substrate. Manipueira comprises a potential alternative culture medium for biosurfactant production by the selected isolates.
\end{abstract}

Key words: biosurfactant, Bacillus, cassava wastewater, agroindustrial wastes

\section{INTRODUCTION}

Surfactants are molecules that concentrate at interfaces and decrease surface and interfacial tension (16). These compounds find applications in an extremely wide variety of industrial processes involving emulsification, foaming, detergency, wetting, dispersing or solubilization $(1,6)$. Currently, almost all the surfactants being produced are chemically derived from petroleum (1).

Naturally occurring surface-active compounds derived from microorganisms, also called biosurfactants, are attracting attention in recent years because they offer several advantages over chemical surfactants, such as low toxicity, inherent good biodegradability and ecological acceptability (2). Most microbial surfactants are complex molecules, comprising different structures that include peptides, glycolipids, glycopeptides, fatty acids and phospholipids $(4,6)$.
Even though interest in biosurfactants is increasing, these compounds do not compete economically with synthetic surfactants. To reduce production costs, different routes could be investigated such as the increase of yields and product accumulation; the development of economical engineering processes, and the use of cost-free or cost-credit feedstock for microorganism growth and surfactant production (12). The choice of inexpensive raw materials is important to the overall economy of the process because they account for $50 \%$ of the final product cost and also reduce the expenses with wastes treatment (10).

The selection of waste substrates involves the difficulty of finding a residue with the right balance of nutrients to support optimal growth and production. Agroindustrial wastes with high content of carbohydrates or lipids meet the requirements for use as substrates for biosurfactant production $(10,12)$. Few attempts at using wastes for biosurfactants production and only few types of biosurfactants produced from wastes have

*Corresponding author. Mailing address: Laboratório de Bioquímica, DCA, FEA, UNICAMP. Rua Monteiro Lobato, 80, C.P. 6121. 13083-970, Campinas, SP, Brasil. Tel.: (+5519) 37882175. Fax: (+5519) 32892832. E-mail: nitschke@ bol.com.br 
been reported. Peat hydrolysate (18), olive oil mill effluent (13), lactic whey (9), soybean curd residue (15), potato process effluent $(7,19)$ and molasses (11) are possible substrates for biosurfactant accumulation.

Cassava flour wastewater (manipueira), cheese whey and molasses are examples of agroindustrial wastes or by-products easily available in Brazil that have a high content of carbohydrates. In this work we report the selection of microorganisms and the evaluation of the use of these unconventional substrates as alternatives for biosurfactant production.

\section{MATERIALS AND METHODS}

\section{Microorganisms}

Eleven biosurfactant producing bacterial isolates were selected by the method described by Mulligan et al. (14) and maintained on nutrient agar (Difco) slants at $4^{\circ} \mathrm{C}$. Standard microbiological test characterized the isolates as gram-positive rods, motile, facultative anaerobes, endospore-forming and catalase positive. Further studies on carbohydrates metabolism were performed using the API $50 \mathrm{CH}$ identification kit (bioMérieux).

\section{Culture media}

- Synthetic medium described by Sheppard and Cooper (17) contained (g/L): glucose, $40 ; \mathrm{NH}_{4} \mathrm{HPO}_{2}, 0.39 ; \mathrm{Na}_{2} \mathrm{HPO}_{4}, 5.67$; $\mathrm{KH}_{2} \mathrm{PO}_{4}, 4.08 ; \mathrm{FeSO}_{4} .7 \mathrm{H}_{2} \mathrm{O}, 0.015 ; \mathrm{MnSO}_{4} . \mathrm{H}_{2} \mathrm{O}, 0.002$; $\mathrm{MgSO}_{4} .7 \mathrm{H}_{2} \mathrm{O}, 0.197 ; \mathrm{CaCl}_{2} .2 \mathrm{H}_{2} \mathrm{O}, 0.001$. Glucose was sterilized separately. Final pH 6.8-6.9.

- Whey from cheese making was collected and stored at $18^{\circ} \mathrm{C}$ until needed. After thawing the substrate was distributed in Erlenmeyer flasks. Initial pH of whey was 6.4.

- Molasses was diluted with distilled water to reach $3 \%(\mathrm{v} / \mathrm{v})$ of soluble solids. The $\mathrm{pH}$ was 5.9-6.0.

- Cassava flour wastewater (manipueira) was stored at $-18^{\circ} \mathrm{C}$ until needed. Natural manipueira (with the presence of insoluble solids) was simply thawed, homogenized and distributed in Erlenmeyer flasks. Decanted manipueira (no insoluble solids) was prepared by heating the thawed waste until boiling to facilitate solids removing. After cooling, the substrate was centrifuged at $10.000 \mathrm{rpm}$ for 20 minutes in a Beckman centrifuge (model J2-21). The supernatant was distributed in Erlenmeyer flasks. The $\mathrm{pH}$ of manipueira media was 5.8 - 5.9 and was not adjusted.

All media were sterilized in autoclave at $1 \mathrm{~atm}, 121^{\circ} \mathrm{C}$ for 15 minutes.

\section{Growth on manipueira agar}

Natural and decanted manipueira prepared as described before were added of $20 \mathrm{~g} / \mathrm{L}$ of agar, sterilized in autoclave and poured into plates. A 24 hours slant culture of each isolate to be tested was spread over a delimited area of $0.5 \mathrm{~cm}$ diameter in the center of the plate with a platinum loop. The plates were incubated for 24 hours at $30^{\circ} \mathrm{C}$, and the diameter of growth was measured in centimeters.

\section{Inoculum and culture conditions}

The bacterial isolates were streaked on a nutrient agar slant and incubated for 24 hours at $30^{\circ} \mathrm{C}$. A loop of culture was inoculated in $20 \mathrm{~mL}$ of nutrient broth (Difco) in a $50 \mathrm{~mL}$ Erlenmeyer flask and incubated in a rotary shaker (New Brunswick) for 24 hours, $120 \mathrm{rpm}$ at $30^{\circ} \mathrm{C}$. An aliquot of $1 \mathrm{~mL}$ of inoculum was transferred to $15 \mathrm{~mL}$ of each production medium contained in a $50 \mathrm{~mL}$ Erlenmeyer flask and incubated at $30^{\circ} \mathrm{C}$ for 72 hours, $150 \mathrm{rpm}$ in an incubator shaker (New Brunswick).

For growth kinetics study, the samples were collected at time-defined intervals and submitted to surface activity measurements, surfactant recovery and viable cell counts.

\section{Analytical measurements}

Viable cell numbers: broth samples were serially diluted and viable counts performed by the spread plate technique.

Culture samples were centrifuged at $10.000 \mathrm{rpm}$ for 20 minutes for cell removal and the supernatant was submitted to surface activity measurements and surfactant recovery.

Surface activity measurement: surface tension and critical micelle dilution $\left(\mathrm{CMD}^{-1}\right.$ and $\left.\mathrm{CMD}^{-2}\right)$ were determined with a Krüss Processor Tensiometer (model K12 T Krüss, Germany) using the plate method. $\mathrm{CMD}^{-1}$ and $\mathrm{CMD}^{-2}$ were determined by measuring the surface tension of 10-times and 100-times diluted broth in distilled water, respectively.

Crude biosurfactant recovery: surfactant was isolated from cell-free broth by precipitation after adjusting broth $\mathrm{pH}$ to 2.0 using $6 \mathrm{~N} \mathrm{HCl}$ and keeping it at $4^{\circ} \mathrm{C}$ overnight. The precipitate thus obtained was pelleted at $10.000 \mathrm{rpm}$ for 20 minutes, dried and weighted.

Biochemical composition of biosurfactant: the crude surfactant obtained from Bacillus LB5a isolate was submitted to protein (8) and lipid (3) determinations.

All experiments were conducted in two independent replicates.

\section{RESULTS AND DISCUSSION}

The criteria adopted for the selection of medium and isolates was the reduction of surface tension to levels about $30 \mathrm{mN} / \mathrm{m}$. The results of the surface tension in the media tested are shown on Table 1. From the eleven isolates tested, eight were capable of surface tension reduction on manipueira medium from 46.75 to values lower than $30 \mathrm{mN} / \mathrm{m}$, while on molasses medium five isolates met the selection requirements criteria. The elevated values of surface tension shown in Table 1 demonstrate that whey is not a good substrate for biosurfactant production by 
the isolates tested. Some isolates were able to produce surface tension around $30 \mathrm{mN} / \mathrm{m}$ on synthetic medium, but it is clear from the data in Table 1, that manipueira gave the lowest surface tension values to all the isolates tested (exception to isolate LB6 that showed the best result on synthetic medium). The average surface tension obtained for molasses was $34.97 \mathrm{mN} /$ $\mathrm{m}$, for manipueira $29.58 \mathrm{mN} / \mathrm{m}$, for whey $43.27 \mathrm{mN} / \mathrm{m}$ and for synthetic medium $36.37 \mathrm{mN} / \mathrm{m}$. Fig. 1 illustrates the percentage of surface tension reduction obtained in each medium by previous selected isolates. A reduction around $42 \%$ was obtained on manipueira whereas for whey the average decrease was inferior to $10 \%$. Molasses and manipueira wastes showed promising results and could be explored as alternative substrates for biosurfactant production.

Critical micelle dilution is an indirect indication of surfactant concentration (11). The lower the CMD values, the higher is the dilution needed to cause a significant change in surface tension, thus higher is the biosurfactant concentration on medium. The five isolates that presented the lowest surface tension values in manipueira and molasses medium were submitted to CMD measurements (Table 2). The $\mathrm{CMD}^{-1}$ and especially $\mathrm{CMD}^{-2}$ data revealed a slightly increase on surface tension when manipueira medium was diluted, suggesting that a high biosurfactant concentration is present in this waste; inversely, for molasses medium the $\mathrm{CMD}^{-2}$ values showed a considerable increase. Manipueira was chosen as a potential substrate for biosurfactant production and the isolates LB2a, LB2b, LB5a, LB262 and LBB that gave the lowest surface tension and CMD on this medium were selected for future investigations. These isolates were subsequently identified as Bacillus sp.

The selected isolates were submitted to biosurfactant production in two different manipueira media: natural manipueira (with the presence of solids) and decanted manipueira (no solids) that was used in the first part of the study. The purpose of this experiment was to evaluate the viability of the use of manipueira waste in its natural form, i.e. without previous treatment, what could reduce costs and facilitate medium preparation. The results shown on Table 3 demonstrate that decanted manipueira is a suitable medium for biosurfactant production. Although the surface parameters had shown higher values for natural manipueira waste, it is important to note that these values were inferior to those obtained for surface tension on synthetic medium and whey (Table 1) as well for $\mathrm{CMD}^{-1}$ and $\mathrm{CMD}^{-2}$ values on molasses (Table 2 ). These results
Table 1. Surface tension obtained on agroindustrial and synthetic media by the isolates tested.

\begin{tabular}{ccccc}
\hline $\begin{array}{c}\text { Medium } \\
\text { Isolates }\end{array}$ & $\begin{array}{c}\text { Synthetic } \\
(\mathrm{mN} / \mathrm{m})\end{array}$ & $\begin{array}{c}\text { Molasses } \\
(\mathrm{mN} / \mathrm{m})\end{array}$ & $\begin{array}{c}\text { Whey } \\
(\mathrm{mN} / \mathrm{m})\end{array}$ & $\begin{array}{c}\text { Manipueira* } \\
(\mathrm{mN} / \mathrm{m})\end{array}$ \\
\hline LB1a & $44.40 \pm 0.16$ & $32.69 \pm 0.22$ & $43.82 \pm 0.07$ & $28.10 \pm 0.33$ \\
LB2a & $41.39 \pm 0.12$ & $27.28 \pm 0.13$ & $44.59 \pm 0.08$ & $26.05 \pm 0.05$ \\
LB2b & $37.27 \pm 0.19$ & $27.00 \pm 0.09$ & $43.31 \pm 0.04$ & $26.17 \pm 0.06$ \\
LB5a & $41.21 \pm 0.18$ & $29.52 \pm 0.01$ & $48.87 \pm 0.19$ & $26.66 \pm 0.02$ \\
LB6 & $32.14 \pm 0.18$ & $40.12 \pm 0.56$ & $42.34 \pm 0.12$ & $35.06 \pm 0.28$ \\
LB114 & $36.91 \pm 0.19$ & $41.07 \pm 0.17$ & $44.74 \pm 0.02$ & $29.57 \pm 0.14$ \\
LB115 & $30.64 \pm 0.20$ & $44.18 \pm 0.81$ & $40.81 \pm 0.02$ & $30.31 \pm 0.05$ \\
LB117 & $30.51 \pm 0.19$ & $42.28 \pm 0.19$ & $35.23 \pm 0.19$ & $29.66 \pm 0.34$ \\
LBA & $41.89 \pm 0.20$ & $44.15 \pm 0.19$ & $43.96 \pm 0.02$ & $41.26 \pm 0.19$ \\
LBB & $30.82 \pm 0.16$ & $28.58 \pm 0.05$ & $43.92 \pm 0.08$ & $26.10 \pm 0.57$ \\
LB262 & $32.65 \pm 0.19$ & $27.76 \pm 0.01$ & $44.44 \pm 0.04$ & $26.48 \pm 0.03$ \\
\hline
\end{tabular}

Initial surface tension of medium: synthetic $46.75 \mathrm{mN} / \mathrm{m}$; whey $49.00 \mathrm{mN} / \mathrm{m}$; molasses $41.74 \mathrm{mN} / \mathrm{m}$; * decanted manipueira $46.68 \mathrm{mN} / \mathrm{m}$.

Table 2. Critical micelle dilution values for the selected isolates growing on molasses and manipueira media.

\begin{tabular}{ccccc}
\hline \multirow{2}{*}{$\begin{array}{c}\text { Medium } \\
\text { Isolates }\end{array}$} & \multicolumn{2}{c}{ Molasses } & \multicolumn{2}{c}{ Manipueira } \\
\cline { 2 - 5 } & $\begin{array}{c}\mathrm{CMD}^{-1} \\
(\mathrm{mN} / \mathrm{m})\end{array}$ & $\begin{array}{c}\mathrm{CMD}^{-2} \\
(\mathrm{mN} / \mathrm{m})\end{array}$ & $\begin{array}{c}\mathrm{CMD}^{-1} \\
(\mathrm{mN} / \mathrm{m})\end{array}$ & $\begin{array}{c}\mathrm{CMD}^{-2} \\
(\mathrm{mN} / \mathrm{m})\end{array}$ \\
\hline LB2a & $35.41 \pm 0.19$ & $71.81 \pm 0.05$ & $26.69 \pm 0.02$ & $31.15 \pm 0.17$ \\
LB2b & $33.04 \pm 0.19$ & $69.20 \pm 0.16$ & $26.67 \pm 0.01$ & $30.80 \pm 0.19$ \\
LB5a & $41.84 \pm 0.27$ & $66.95 \pm 0.20$ & $27.00 \pm 0.02$ & $32.33 \pm 0.18$ \\
LBB & $38.47 \pm 0.19$ & $61.50 \pm 0.25$ & $27.91 \pm 0.06$ & $35.80 \pm 0.19$ \\
LB262 & $34.40 \pm 0.19$ & $70.12 \pm 0.16$ & $26.86 \pm 0.02$ & $31.38 \pm 0.18$ \\
\hline
\end{tabular}

Table 3. Comparison of surface properties obtained by the isolates on natural and decanted manipueira.

\begin{tabular}{lcccccc}
\hline \multirow{2}{*}{ Isolates } & \multicolumn{3}{c}{ Natural manipueira } & \multicolumn{2}{c}{ Decanted manipueira } \\
\cline { 2 - 7 } & $\begin{array}{c}\mathrm{ST} \\
(\mathrm{mN} / \mathrm{m})\end{array}$ & $\begin{array}{c}\mathrm{CMD}^{-1} \\
(\mathrm{mN} / \mathrm{m})\end{array}$ & $\begin{array}{c}\mathrm{CMD}^{-2} \\
(\mathrm{mN} / \mathrm{m})\end{array}$ & $\begin{array}{c}\mathrm{ST} \\
(\mathrm{mN} / \mathrm{m})\end{array}$ & $\begin{array}{c}\mathrm{CMD}^{-1} \\
(\mathrm{mN} / \mathrm{m})\end{array}$ & $\begin{array}{c}\mathrm{CMD}^{-2} \\
(\mathrm{mN} / \mathrm{m})\end{array}$ \\
\hline LB2a & 30.51 & 31.95 & 41.17 & 26.57 & 26.85 & 31.36 \\
LB2a & 30.51 & 31.95 & 41.17 & 26.57 & 26.85 & 31.36 \\
LB2b & 30.32 & 31.72 & 38.70 & 26.83 & 27.19 & 32.57 \\
LB5a & 29.02 & 29.84 & 36.75 & 26.95 & 27.24 & 33.23 \\
LBB & 30.53 & 31.78 & 36.89 & 26.43 & 29.43 & 46.49 \\
LB262 & 30.10 & 31.10 & 42.13 & 26.64 & 32.01 & 44.29 \\
ATCC21332 & 41.56 & 49.82 & 68.16 & 27.93 & 38.17 & 58.04 \\
\hline
\end{tabular}

Maximum standard deviation: 0.20 ST: surface tension 


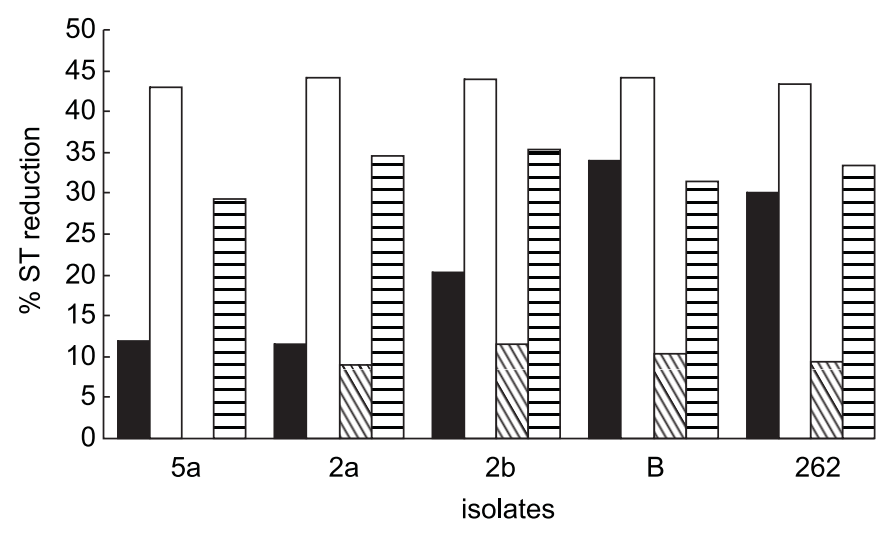

synthetic $\square$ manipueira $\mathbb{M}$ whey $\equiv$ molasses

Figure 1. Percentage of surface tension reduction obtained by the selected isolates on agroindustrial and synthetic media.

demonstrate that natural manipueira could also be an appropriate substrate for biosurfactant production by the selected isolates. The strain B. subtilis ATCC 21332 is a standard for the production of the lipopeptide called surfactin, one of the most effective biosurfactants found so far (5). The data in Table 3 show that biosurfactant production on manipueira medium by ATCC 21332 strain was poor when compared with the production by the selected Bacillus sp. isolates. This fact suggests that the isolates are more adapted to biosurfactant production on cassava wastewater than the standard strain. However, the isolates could also belong to different species thus could demand different nutritional requirements for surfactant biosynthesis.

The ability of each isolate to grow on manipueira was investigated and the results are shown in Table 4. The strain ATCC 21332 grew poorly on manipueira medium confirming the suggestions above. The isolate LBB also showed a poor growth on manipueira agar, but surface tension values for this microorganism were low. Probably biosurfactant production by this isolate is not related to cell growth, even though Vater (20) reported that biosurfactant production by Bacillus is associated with cellular growth. The isolate LB5a showed the largest growth diameter on both types of manipueira medium suggesting that this microorganism is greatly adapted to these substrates. Considering the ability for growth and for biosurfactant accumulation on natural and decanted manipueira the isolate LB5a was chosen for future work.

The biosynthesis of surfactant by Bacillus sp. LB5a in decanted manipueira medium started on the exponential growth phase and continued during the stationary phase, therefore, it can not be stated that biosurfactant production by $B$. subtilis LB5a is growth-associated (Fig. 2). However, It is interesting to note that about $50 \%(1.09 \mathrm{~g} / \mathrm{L})$ of the surfactant was produced

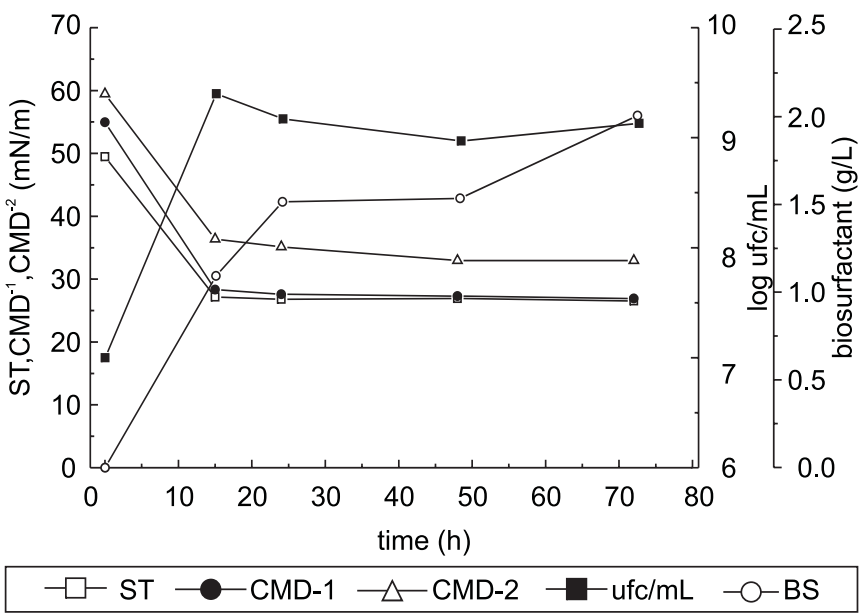

Figure 2. Kinetics of biosurfactant production by Bacillus LB5a in decanted manipueira medium (ST: surface tension BS: biosurfactant CMD: critical micelle dilution).

Table 4. Growth diameter of the selected isolates on manipueira agar.

\begin{tabular}{lccc}
\hline \multirow{2}{*}{ Isolates } & \multicolumn{3}{c}{ Diameter of growth $(\mathrm{cm})^{*}$} \\
\cline { 2 - 4 } & $\begin{array}{c}\text { Natural } \\
\text { manipueira }\end{array}$ & $\begin{array}{c}\text { Decanted } \\
\text { manipueira }\end{array}$ & $\begin{array}{c}\text { Growth } \\
\text { Average }\end{array}$ \\
\hline LB2a & 5.4 & 3.5 & 4.4 \\
LB2b & 5.2 & 6.3 & 5.7 \\
LB5a & 6.5 & 8.0 & 7.2 \\
LBB & 2.4 & 2.2 & 2.3 \\
LB262 & 5.2 & 7.6 & 6.4 \\
ATCC21332 & 3.3 & 3.8 & 3.5 \\
\hline
\end{tabular}

* average of two independent replicates.

during the first 15 hours and further accumulation occurred slowly reaching $2.0 \mathrm{~g} / \mathrm{L}$ only after 72 hours. Cooper et al. (5) also observed that surfactin production by B. subtilis 21332 started during the exponential phase and was continued during the stationary growth phase. The manipueira medium proved to be a suitable substrate for both bacterial growth and surfactant accumulation by the selected microrganism.

Preliminary biochemical characterization of the surfactant produced by LB5a isolate growing on manipueira medium showed that the product contains $53.6 \%(\mathrm{w} / \mathrm{w})$ of lipids and $38.5 \%(\mathrm{w} / \mathrm{w})$ of proteins. These results suggest that the surfactant has a lipopeptide nature, probably related to the surfactin family of surface-active compounds which are characteristics of some Bacillus strains $(15,17)$. 
When alternative substrates such as agroindustrial wastes are being investigated, the screening for microorganisms that have high potential for substrate utilization and product accumulation is of great importance. Cassava flour wastewater (manipueira) offers promise as nutrients source for biosurfactant production by Bacillus sp. isolates and the use of natural manipueira could reduce the economics of process and residue treatment. Future work should be done in order to investigate the properties and chemical structure of the surface-active compound.

\section{ACKNOWLEDGMENTS}

Authors thank to CAPES and FAPESP for financial support and to Plaza S/A for cassava wastewater supply.

\section{RESUMO}

\section{Seleção de microrganismos para a produção de biossurfatantes em resíduos agroindustriais}

Alguns isolados bacterianos foram avaliados quanto à capacidade de produção de biossurfatantes a partir de melaço, soro de leite e manipueira como substratos. A produção nestes meios alternativos foi comparada com a produção em meio de cultura convencional. Dentre os meios testados, a manipueira demonstrou a maior percentagem de redução na tensão superficial atingindo valores ao redor de $42 \%$. Dos onze isolados testados, oito foram capazes de diminuir a tensão superficial para níveis inferiores à $30 \mathrm{mN} / \mathrm{m}$ utilizando manipueira como substrato. Os isolados LB 5a, LB2a, LB262, LBB e LB1a apresentaram tensão superficial em torno de $26 \mathrm{mN} / \mathrm{m}$ sendo selecionados e posteriormente identificados como pertencentes ao gênero Bacillus sp. A manipueira natural (alto teor de sólidos) e a manipueira decantada (ausência de sólidos) foram investigadas como meios de cultivo para produção de biossurfatantes pelos microrganismos selecionados. O meio de manipueira natural apresentou tensão superficial minima de 28 $\mathrm{mN} / \mathrm{m}$ (isolado LB5a) enquanto que o meio de manipueira decantada apresentou tensão superficial mínima de $26 \mathrm{mN} / \mathrm{m}$ (isolado LB2a). O diâmetro de crescimento médio do isolado LB5a em ágar manipueira foi de $7.2 \mathrm{~cm}$ sugerindo maior capacidade de crescimento neste substrato. A manipueira demonstrou potencial como meio de cultura alternativo para a produção de biossurfatantes pelos isolados selecionados.

Palavras-chave: biossurfatantes, biotensoativos, Bacillus, manipueira, resíduos agro-industriais

\section{REFERENCES}

1. Banat, I.M.; Makkar, R.S.; Cameotra, S.S. Potential commercial applications of microbial surfactants. Appl. Microbiol. Biotechnol., 53: 495-508, 2000 .

2. Banat, I.M. Les biosurfactants, plus que jamais sollicités. Biofutur, 198: 44-47, 2000.

3. Bligh, E.C.; Dyer, W.J. A rapid method of total lipid extration and purification. Can. J. Biochem. Physiol., 37: 911-917, 1959.

4. Cameotra, S.S.; Makkar, R.S. Synthesis of biosurfactants in extreme conditions. Appl. Microbiol. Biotechnol, 50: 520-529, 1998.

5. Cooper, D.G.; Macdonald, C.R.; Duff, S.J.B.; Kosaric, N. Enhanced production of surfactin from Bacillus subtilis by continuous product removal and metal cation additions. Appl. Environ. Microbiol., 42: 408-412, 1981.

6. Desai, J.D.; Banat, I.M. Microbial production of surfactants and their commercial potential. Microbiol. Mol. Rev., 61: 47-64, 1997.

7. Fox, S.L.; Bala, G.A. Production of surfactant from Bacillus subtilis ATCC 21332 using potato substrates. Biores. Tech., 75: 235-240, 2000 .

8. Gornall, A.G.; Bardawill, C.S.; David, M.M. Determination of serum protein by means of the Biuret reaction. J. Biol. Chem., 177: 751756, 1949.

9. Koch, A.K.; Reiser, J.; Kappeli, O. Genetic construction of lactose utilizing strains of Pseudomonas aeruginosa and their application in biosurfactant production. Biotechnol., 6: 1335-1339, 1988.

10. Makkar, R.S.; Cameotra, S.S. Biosurfactant production by microorganisms on unconventional carbon sources. J. Surf. Det., 2: 237-241, 1999

11. Makkar, R.S.; Cameotra, S.S. Utilization of molasses for biosurfactant production by two Bacillus strains at thermophilic conditions. JAOCS, 74: 887-889, 1997.

12. Mercade, M.E.; Manresa, M.A. The use of agroindustrial by-products for biosurfactant production. JAOCS, 71: 61-64, 1994.

13. Mercade, M.E.; Manresa, M.A.; Robert, M.; Espuny, M.J.; Andres, C.; Guinea, J. Olive oil mill effluent (OOME): new substrate for biosurfactant production. Bioresour. Technol., 43: 1-6, 1993.

14. Mulligan, C.N.; Cooper, D.G.; Neufeld, R.J. Selection of microbes producing biosurfactants in media without hydrocarbons. J. Ferment. Technol., 62: 311-314, 1984.

15. Ohno, A.; Takashi, A.; Shoda, M. Production of a lipopeptide antibiotic, surfactin, by recombinant Bacillus subtilis in solid state fermentation. Biotechnol. Bioeng., 47: 209-214, 1995.

16. Rosenberg, E.; Ron, E.Z. High and low-molecular-mass microbial surfactants. Appl. Microbiol. Biotechnol., 52: 154-162, 1999.

17. Sheppard, J.D.; Cooper, D.G. The response of Bacillus subtilis ATCC21332 to manganese during continuous-phased growth. Appl. Microbiol. Biotechnol., 35: 72-76, 1991.

18. Sheppard, J.D.; Mulligan, C. The production of surfactin by Bacillus subtilis grown on peat hydrolysate. Appl. Microbiol. Biotechnol., 27: 110-116, 1987

19. Thompson, D.N.; Fox, S.L.; Bala, G.A. Biosurfactants from potato process effluents. Appl. Biochem. Biotechnol., 84/86: 917-929, 2000.

20. Vater, J. Lipopeptides, an attractive class of microbial surfactants Prog. Coll. Polymer Sci., 72: 12-18, 1986 